\title{
Design and Development of Cow Dung Stick Manufacturing Machine
}

\author{
${ }^{1}$ Musthak I Ansari, ${ }^{2}$ Mohammadsahul S Badarpura, ${ }^{3}$ Purvesh J. Pandya, ${ }^{4}$ Durgesh B. Prajapati, \\ ${ }^{5}$ Vaishal J. Banker, ${ }^{6}$ Mitul R. Malli \\ ${ }^{1,2,3,4}$ UG Students, ${ }^{5,6}$ Assistant Professor, Mechanical Engineering Department, A D Patel Institute \\ of Technology, Anand, Gujarat, India. \\ 1'mustaq740@gmail.com, ${ }^{2}$ sahulbadarpura838@gmail.com, ${ }^{3}$ pjpandya20699@gmail.com, \\ 4durgeshprajapati316@gmail.com, ${ }^{5}$ bvaishal@gmail.com, ${ }^{6}$ er.mitulmalli@gmail.com
}

Abstract From the ancient times, cow and cow dung are closely with Indian culture.In present scenario, as the productivity of cow milk is less compared to the milk of buffaloes and hybrid animals, but the dung of the cow having good potential as a fuel and fertilizer. To use cow dung as a fuel in a present scenario is difficult to handle due to the size and shape of cow dung and so the best option is to convert cow dung into some typical shape like stick, so that it can be easily handled. Fulfillment of this objective is the aim of present work by developing appropriate machine for mentioned purpose.

Keywords —Cow dung stick, Economical, Fuel, Hopper, motor, screw conveyer, Die

\section{INTRODUCTION}

Conventionally fire wood, electricity or LPG gas is used for cremation purpose. Indian people mostly prefer traditional product for cremation e.g. wooden logs and dried cow dung sticks. Compared to fire wood and other alternatives, cremation using cow dung logs cost less. This has lead to the increased demand of cow dung sticks but due to difficulty in manufacturing long logs, availability remains a problem [1-3]. This opportunity of innovation inspired us to develop a machine that makes long cow-dung sticks with minimum human intervention.

A combination of dung and straw (or any agro waste/harvested crop residues) is fed into the hopper of the machine. Screw mechanism has been provided in the machine, which helps in mixing raw materials thoroughly, compress them and extrude them out. By using different size of die, logs of different shapes and sizes can be made easily. Produced logs are then put under the sunlight to dry out the moisture inside them, making them hard and sturdy.

\section{Current Status}

The country like India where $70 \%$ people associated with farming activity the waste produce after farming which consists of good energy content called bio mass can be used as energy source.

Biomass is a term for all organic material that stems from plants (including algae, trees and crops). Biomass is produced by green plants converting sunlight into plant material through photosynthesis and includes all land- and water-based vegetation, as well as all organic wastes [4-6]. The biomass resource can be considered as organic matter, in which the energy of sunlight is stored in chemical bonds.

When the bonds between adjacent carbon, hydrogen and oxygen molecules are broken by digestion, combustion, or decomposition, these substances release their stored, chemical energy. Biomass has always been a major source of energy for mankind and is presently estimated to contribute of the order $10-14 \%$ of the world's energy supply.

Biomass is the plant material derived from the reaction between $\mathrm{CO} 2$ in the air, water and sunlight, via photosynthesis, to produce carbohydrates that form the building blocks of biomass. Typically photosynthesis converts less than $1 \%$ of the available sunlight to stored. Most biomass used today is home grown energy. Woodlogs, chips, bark, and sawdust- accounts for about 46 percent of biomass energy. But any organic matter can produce biomass energy [7-9].

Other biomass sources include agricultural waste products like fruit pits and corncobs. Wood and wood waste, along with agricultural waste, are used to generate electricity.

Much of the electricity is used by the industries making the waste; it is not distributed by utilities, it is cogenerated. Paper mills and saw mills use much of their waste products to generate steam and electricity for their use. Burning trash turns waste into a usable form of energy. One ton $(2,000$ 
pounds) of garbage contains about as much heat energy as 500 pounds of coal. Garbage is not all biomass; perhaps half of its energy content comes from plastics, which are made from petroleum and natural gas. Power plants that burn garbage for energy are called waste-to-energy plants. Bacteria and fungi are not picky eaters. They eat dead plants and animals, causing them to rot or decay.

A fungus on a rotting log is converting cellulose to sugars to feed itself. New regulations require land- 11 to collect methane gas for safety and environmental reasons. Methane gas is colorless and odorless, but it is not harmless. Methane can also be produced using energy from agricultural and human wastes.

\section{Problem Description}

In the era of machinery our Indian farmers are still using old methods for the preparation of cow dung products. There are many backward villages which still use their hands for the preparation of the cow dung cakes and patties these practices often lead to infections and diseases as the dung get clanged in the nails and when the eat there are chances that they can swallow the waste also. No doubt there are also machines available which help them in their work but the heavy cost of the setup makes it impossible to buy and use.

\section{Design \& MANufacturing}

\section{A. Components of the Machine}

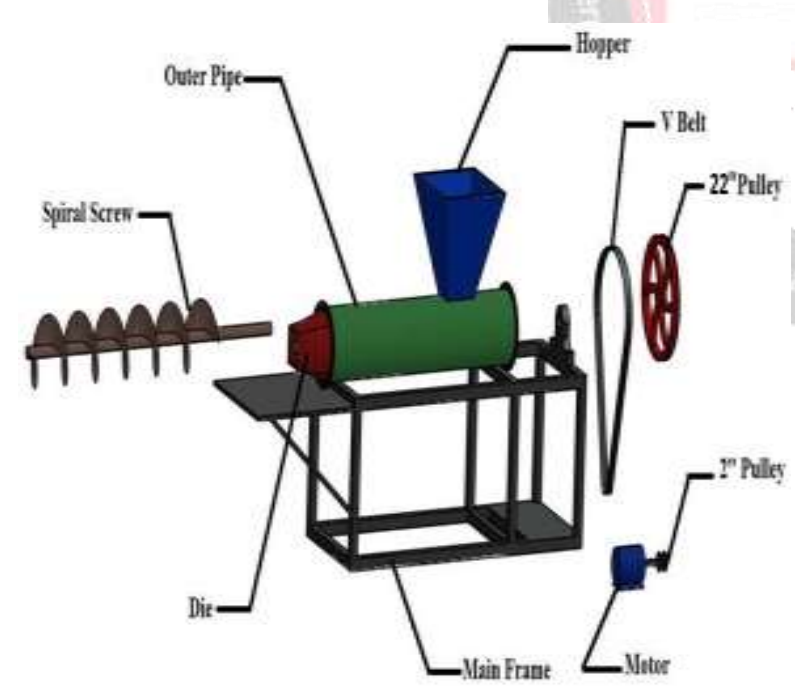

Figure 1: CAD Geometry of Model developed in Solidworks

The whole set up is divided into small components (Fig. 1)

- Main frame-holds the other components

- Motor-power source $0.5 \mathrm{HP}$

- Pulleys-power transmission

- V belt-power transmission

- Hopper-feeding the raw material into machine

- Outer pipe-holds the screw conveyor

- Screw conveyor-mix the material and extrude out

- Die-gives proper shape to the product

- Shaft-power transmission
- Bearing-holding shaft

\section{B. Method Adopted to make the stick}

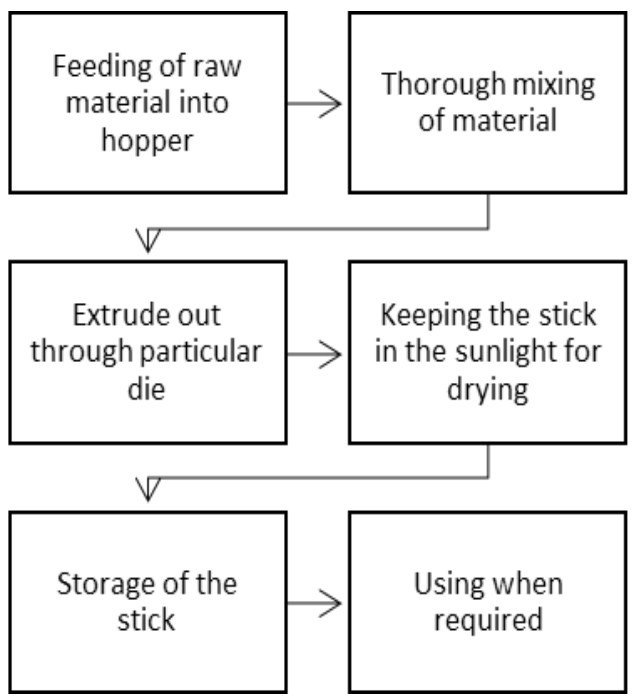

Figure 2: Methodology

Fig. 2 shows the methodology adopted to manufacture sticks. Firstly, the raw material which is a mixture of water and dung is fed into a hopper wherein the mixing takes place. It is extruded into desired length of stick with the help of extruder. Once the stick is extruded, it is then allowed to be kept in sunlight for drying. Finally, the stick is ready to use once it is dried.

\section{Design Calculations}

\section{HERE,}

Power(P) $=0.5$ H.P

Number of Rotation of motor $\left(\mathrm{N}_{1}\right)=1440$ RPM

Number of Rotation of pulley $=\mathrm{N}_{2}$

Diameter of small pulley $\left(\mathrm{D}_{1}\right)=2 \times 25.4 \mathrm{~mm}$

Diameter of large pulley $\left(D_{2}\right)=22 \times 25.4 \mathrm{~mm}$

[1] For no. of rotations of pulley:-

$N_{1} / N_{2}=D_{2} / D_{1}$

$\therefore$ 1440/N_2 $=558.8 / 5.08$

$\therefore \mathrm{N} 2=130 \mathrm{RPM}$

$\therefore \mathrm{N}_{2}=130$ RPM

[2] For Torque :-

$\mathrm{P}=(2 \pi N T) / 60$

.. $0.5 \times 746=2 \pi X 130 X T / 60$

$\therefore \mathrm{T}=27.41 \mathrm{Nm}$

$\therefore \mathrm{T}=27.41 \mathrm{X} 103$ N.mm

[3] For Diameter of shaft :$\mathrm{T}=$ " $\pi \mathrm{D}^{3} \tau " / 16$

$\therefore 27.41 \times 10^{3}=\pi$ X D3 X $45 / 16$

$\therefore\left(27.41 X 10^{3} \times 16\right) / \pi X 45=\mathrm{D}^{3}$

$\therefore \mathrm{D}=14.58 \mathrm{~mm}$

[4] For Force :-

$\mathrm{T}=\mathrm{F} \mathrm{X} \mathrm{R}$

$: 27.41$ X $10^{3}=$ F X 11 X 25.4

$\therefore \mathrm{F}=27.41 \times 10^{3} / 11 X 25.4$

$\therefore \mathrm{F}=98.10 \mathrm{~N}$ 


\section{Final Assembly of Machine}

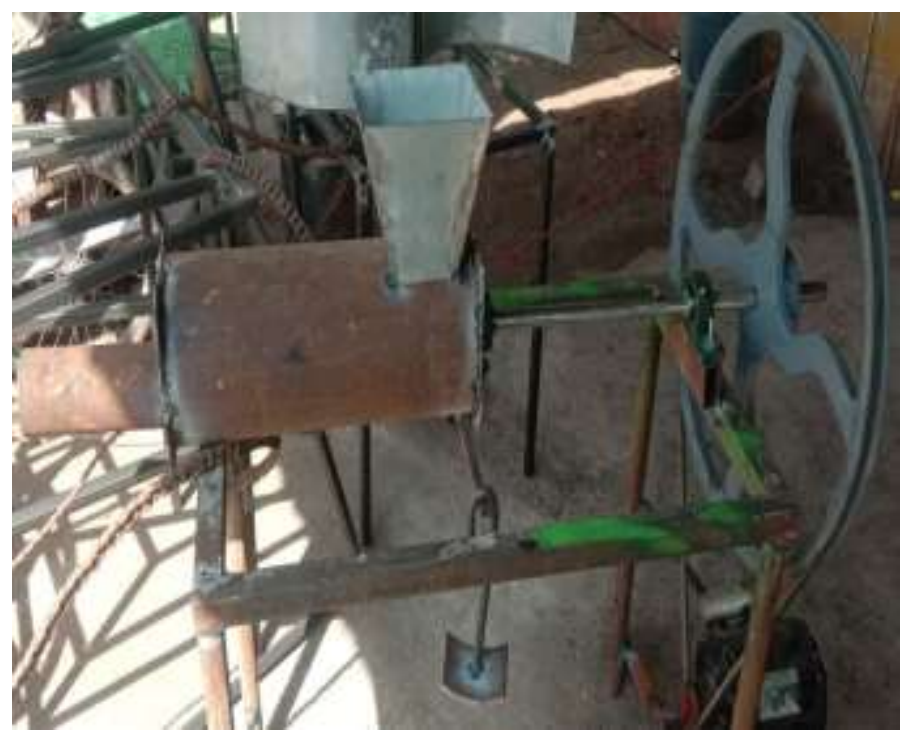

Figure 3: Assembly of Machine

Fig. 3 shows the assembly of the machine sticks. CAD geometry of model was developed in Solidworks and then the parts were manufactured.

\section{E. Cost Analysis \& Findings}

Table 1 shows the cost analysis for the manufactured machine. The sticks manufactured are of good calorific value compared to coal and other fuels. Also, the development of dust and ash is also minimum as the sticks are a form of biomass. Our main goal was to manufacture a machine which is able to be developed at a low cost compared to others and provide the same to the industries/places where conventional fuels are utilized.

Table 1: Cost Analysis for the Machine

\begin{tabular}{|c|c|c|}
\hline Sr. No. & Name of Components & Cost \\
\hline 1 & $2 "$ and $10 "$ pulley (B section) & $2000 /-$ \\
\hline 2 & $\mathrm{~V}$ belt (B section) & $500 /-$ \\
\hline 3 & $\begin{array}{l}\text { Bearing ( } 4 \text { Nos., } 20 \mathrm{~mm} \\
\text { diameter) }\end{array}$ & $1500 /-$ \\
\hline 4 & $\begin{array}{l}\text { Frame }(25 \mathrm{~mm} \text { X } 25 \mathrm{~mm} \mathrm{X} 5 \\
\mathrm{mm})\end{array}$ & $1000 /-$ \\
\hline 5 & Blacksmith work & $4000 /-$ \\
\hline 6 & Machining work & $7000 /-$ \\
\hline 7 & Paint & $3000 /-$ \\
\hline 8 & Others & $1500 /-$ \\
\hline 9 & Motor $1-\Phi, 230 \mathrm{~V}, 50 \mathrm{~Hz}$ & $3000 /-$ \\
\hline 10 & Screw Conveyor & $4000 /-$ \\
\hline & Total & 27,500/- INR \\
\hline
\end{tabular}

\section{Conclusion}

The development of the "cow dung stick manufacturing machine" is successfully completed that uses different types of agricultural waste along with the cow dung to give out stick which can be used for different purposes like feeding in boiler for easy start, fuel for house hold, manure for field, preparation of food by burning. The machine design and manufacturing were done in-house only with minimum cost and maintaining the quality of sticks. The machine is cheap as compared to the machines available in the market the now the cattle owner can easily prepare the sticks with less human intervention.

\section{REFERENCES}

[1] Meng, Q. M., Li, J. X., Chun, T. J., He, X. F., Wei, R. F., Wang, P., \& Long, H. M. (2017). Effects of Treated Cow Dung Addition on the Strength of Carbon-Bearing Iron Ore Pellets. Advances in Materials Science and Engineering, 2017.

[2] Godi, N. Y., Zhengwuvi, L. B., Abdulkadir, S., \& Kamtu, P. (2013). Effect of cow dung variety on biogas production. Journal of mechanical engineering research, 5(1), $1-4$.

[3] Avinash, A., \& Murugesan, A. (2017). Chemometric analysis of cow dung ash as an adsorbent for purifying biodiesel from waste cooking oil. Scientific reports, 7(1), 1-8.

[4] Yalley, P. K., \& Manu, D. (2013). Strength and Durability Properties of Cow Dung Stabilised Earth Brick. Civil and Enviromental Research, 13(3).

[5] Al Mamun, M. R., Kabir, M. S., Alam, M. M., \& Islam, M. M. (2007). Utilization pattern of biomass for rural energy supply in Bangladesh. Bangladesh Agricultural University.

[6] Frías, M., \& Rivera, J. (2004). Influence of calcining conditions on pozzolanic activity and reaction kinetics in paper sludge-calcium hydroxide mixes. Special Publication, 221, 879-892.

[7] Yalley, P. K., \& Manu, D. (2013). Strength and Durability Properties of Cow Dung Stabilised Earth Brick. Civil and Enviromental Research, 13(3).

[8] Obichigha, P. C. (2005). Design, Construction and Testing of a Biogas Digester. Mechanical Engineering, Federal University of Technology, Yola, 24-26.

[9] Cheremisinoff, N. P., Cheremisinoff, P. N., \& Ellerbusch, F. (1980). Biomass: Applications, technology, and production. 